\title{
THE ROMANIZATION OF ENGLISH LAW
}

In the Island of Britain was established a Roman province which lasted four hundred years. Julius Cæsar's expedition into Britain 55 B. C. was followed a century later by permanent conquest and occupation of the island, and the introduction of Roman civilization. Britain was from the outset an imperial command of the first rank, garrisoned at one time by about 30,000 Roman soldiers, ${ }^{1}$ and became an important Roman governorship.

Roman law made rapid stricles in Britain during the second and third centuries A. D., as is attested by the writings of the Roman jurists Javolenus and Ulpian, who discussed cases arising in Britain. ${ }^{2}$ Moreover, an illustrious galaxy of Roman judges honored Britain with their presence. York was the seat for three years of the two highest Roman tribunals, with Fapinian, the prince of Roman jurisconsults, as chief justice, and the famous Ulpian and Paulus as associate justices, ${ }^{3}$-a wonderfully able and brilliant court. It was as if the United States Supreme Court were to hold sessions in Alaska.

And when the Roman Empire decayed in the fifth century, "it was not Britain that gave up Rome, but Rome that gave up Britain".4 In the year 455 the Roman legions were withdrawn from Britain to defend Italy against the barbarian German invaders. Soon, in addition to the roving Scots, the Angles and Saxons from Germany began to invade Britain, and the doom of the helpless island was settled. The inhabitants in despair addressed the Emperor Honorius for protection against the Saxons, but he replied that they must help themselves as best they could.

But the influence of Rome reappeared in Britain under another guise late in the sixth century when Christianity was reintroduce:l and the Anglo-Saxon invaders were converted to the Christian religion. In 596 Pope Gregory I. sent over to the island or Britain the famous St. Augustine, founder of the primate English see of Canterbury, by whose efforts and those of his colleagues the Anglo-Saxons abandoned paganism and became Christians.

1 Mommsen, Provinces of the Roman Empire (Dickson's translation), Vol. I, ch. 5, p. 190.

2 Mommsen, The Provinces, p. 194.

3 Walton, Introduction to Roman Laze, p. 140.

4 Mommsen, The Provinces of the Roman Empirc, Vol. I, ch. 5, p. 194. 
One of Augustine's converts was Ethelbert, King of Kent, who soon revealed Roman influences by setting in writing the laws of his kingdom "according to the Roman mode"..$^{-}$This he did about the year 600 . Very likely the Roman missionaries had brought to his attention the exploits of Justinian, then dead scarcely forty years. Ethelbert's laws are the earliest document in the English language, the first laws written in a Germanic tongue.

Through the fostering care of the Christian clergy, whose personal law was the Roman law, knowledge of the Roman law was kept alive in the island of Britain from the seventh to the eleventh century; it is known that during these centuries Roman law was studied in the cathedral school at York. ${ }^{8}$

In 827 the united kingdoms of the Angles and Saxons received the name of "Angle-land" (England), the kingdom of England beginning in the reign of Egbert. Much legislation came from the later kings of this Anglo-Saxon monarchy. There is a real continuity of English law from the time of Alfred the Great ${ }^{7}$ until now. By Alfred and his Saxon successors a remarkable series of laws was published which strongly resemble the Frankish capitularies of Charlemagne and the later Carlovingians. ${ }^{8}$ Now Charlemagne, the first emperor of the revived medieval Roman Empire of the West, had tried to substitute Roman legal ideas and law for Teutonic usages.

Alfred did much for the law of his age, endeavoring to gather all that seemed good in the old English laws and promulgating new laws. A visit to Rome in his youth and his intense desire after he became king to import into England the learning of the continent should account for much of his inspiration as a legislator.

The eleventh century Canute, the Danish king who ruled both England $^{9}$ and Denmark, was perhaps the greatest European leg-

5 Bede, Hist. eccl. II, ch. 5, "juxta exempla Romanorum".

-Alcuin,-Pocma: "Ilios juridica curavit cote polire".

Savigny, Geschicte d. röm. Rechts im Mitielalter, ch. 6 , \$135.

Alcuin (c. 735-804) the eminent eighth century English educator, renowned for his work at the Palace School of Charlemagne, has left us a valuable description of the academic life at York during his fifteen years' residence there as an instructor.

7 Reigned 871-901.

8 Stubbs, Const. Hist., I, 223.

9 1016-1035. 
islator of that century ${ }^{10} \mathrm{He}$, too, had visited Rome; he was personally acquainted with an emperor and a pope. His comprehensive statutes helped enormously to add to the continuity of English law from Alfred's day.

The restoration of the old Anglo-Saxon dynasty in the person of Edward the Confessor, ${ }^{11}$ who had spent the best years ${ }^{12}$ of his life in exile on the continent, inevitably continued Roman influences in Saxon England. Edward's predilection for foreigners, especially Normans, is well known. It is interesting to notice that Edward returned ${ }^{13}$ to England just before the time ${ }^{14}$ the rehabilitation of Roman law began on the continent.. ${ }^{15}$ Edward is honored by tradition as a pre-eminent legislator, although what now remains of his laws was compiled after the Norman Conquest. $^{18}$ The most trustworthy manuscript ${ }^{17}$ contains quite a few fragments of Roman law. ${ }^{18}$ One thing is certain: the Saxon law of Edward's time must be included in the basis of the later English common law, for this law was the standard of conduct constantly elevated before the early Norman kings, ${ }^{19}$ who swore to keep the laws of King Edward in order to obtain the favor of their subjects.

10 "If he is not the greatest legislator of the eleventh century, we must go as far as Barcelona" (i.e., for the medieval compilation known as the Consolato del Mare) "to find his peer",-Pollock and Maitland, History of English Law2, Vol. I, p. 20.

11 Reigned 1042-1066.

12 About thirty years, from about his tenth to his fortieth year ( $c$. 1013-1042.)

13 His return was in 1042.

${ }^{14}$ The date may be given as 1038,-Pollock and Maitland, History, ${ }^{2}$ Vol. I, p. 23.

15 This movement began in Italy, the Institutes of Justinian being studied at Pavia in the eleventh century, and was later known as the Bologna revival of Roman law.

${ }_{16}$ Pollock and Maitland, Fist. of English Law,2 Vol. I, p. 97-104: Holdsworth, History of English Law, Vol. I, p. 2. These are the Leges Henrici I (composed about 1118), the Quadripartitus (1113-1118), the Bilingual Laws of William $I$, and the Leges Edwardi Confessoris. These documents contain many laws of Canute.

${ }^{17}$ The Leges Willelmi I (Leis Williame), known also as the Bilingual Lazes of William $I$.

${ }^{18}$ See Pollock and Maitland, History of English Law ${ }^{2}$, Vol. I, p. 102, note 1; Holdsworth, History of English Law, Vol. I, p. 2.

10 William the Conqueror, Henry $I$ and Stephen, for example: see Pollock and Maitland, History ${ }^{2}$, Vol. I, p. 88, 95, 96. 
The turmoil of the centuries from the cessation of the Roman dominion in Britain to the Norman conquest, together with the rudeness of the Saxon invaders, was hostile to civilizing influences from abroad. All this unfavorably affected the development of Saxon English law; it accounts for the few traecs of Roman law in England after the Saxon conquest, which at best are obscure and hard to find. England seemed in danger of being lost to the civilizing influence of Roman law.

The winning of the battle of Hastings in 1066 made the Normans from France masters of England, and brought England once more into direct relations with the continent whence she was to derive advancement in civilization and progress in law.

William the Conqueror and his sons 20 introduced marked changes in English law. William's great prime minister and right hand man was the Italian Lanfranc, whom he persuaded to become Archbishop of Canterbury. It should never be forgotten that Lanfranc, although a great prelate and theologian, was a most accomplished lawyer, well-known throughout the world of his time. He had studied Roman law at Pavia in his native Italy, and while a layman had gone to Normandy, where he had taught at Avranches and Bec. ${ }^{21}$ It is not at all impossible that he taught law in these places, and so prepared the Normans for their great undertaking by supplementing the soldier's task of conquest with the work of the lawyer. It is idle to say that the English law of the twelfth century has no Roman element in it derived from Italy, when there had existed in England late in the preceding century a person of vast constructive judicial influence like Lanfranc, who possessed a most profound knowledge of Roman law and Canon law in addition to his mastery of the rude English law of his age.

Before the middle of the twelfth century was reached three great improvements had been made in English law, all of which helped to pave the way for a real reception of Roman law into England and its establishment as a source of the English common law. (1) Central courts of justice were established, and the Saxon local courts fell into disfavor. ${ }^{22}$ (2) Ecclesiastical courts

20 The reigns of William the Conqueror and his sons were from 1066 to 1134 (or to 1154 , if that of Stephen, William's grandson, be also included).

${ }^{21}$ Savigny, Geschichte, ch. 6, $\$ 135$; Pollock and Maitland, History ${ }^{2}$. Vol. I, p. 77-78.

22 Pollock and Maitland, History ${ }^{2}$, Vol. I, p. 108, 138. 
were separated from civil courts: ${ }^{28}$ this change favored the Roman law and the Canon law, which were given a free course in the English ecclesiastical courts without any checks by the English customary law. (3) The administration of justice was put in the hands of the educated men of the day,-usually the men with a clerical education who were university-trained and familiar with Latin forms of expression. ${ }^{24}$ Norman-French was made the language of the law courts,- a provision which lasted for over two centuries. ${ }^{25}$ By these measures the old native Saxon law was very largely upset.

The twelfth and thirteenth centuries form the greatest landmark in the history of English law; for the Bologna revival of Roman law reached England in the twelfth century. Not long after the school of the Glossators was inaugurated at Bologna, the Lombard Vacarius came over to England in 1149 with Theobald, Archbishop of Canterbury. Vacarius was appointed professor at the young University of Oxford, ${ }^{26}$ and began to lecture on Roman law according to the methods employed by the Italian Glossators. Vacarius published an abbreviation in nine books of the Code and Digest of Justinian for the use of students too poor to obtain copies of the originals. ${ }^{27}$ The new teaching of Vacarius aroused opposition, so much so that King Stephen, who disliked Archbishop Theobald, prohibited Vacarius from teaching, and forbacle even the retention in one's possession of the obnoxious books of Roman law; but the persecution soon failed, and the royal prohibitions were speedily removed either by Stephen or his successors. ${ }^{28}$

That the sources of Roman law, both the Justinian and the ante-Justinian, were known in England by the middle of the

23 Pollock and Maitland, History ${ }^{2}$, Vol. I, p. 124.

24 Amos, Roman Civil Law, p. 444.

25 Amos, Roman Civil Law, p. 444.

${ }^{26}$ When Oxford was founded is lost in obscurity. The traditional date is 879 , during the reign of Alfred the Great; but it is generally held that Oxford was founded early in the twelfth century (c. 1100?). See Goldwin Smith, History of England, Vol. I, p. 58, and his Oxford and Her Colleges, p. 25.

27 Vacarius' book was entitled 'Liber ex universo enucleato juris exceptus, et pauperibus praesertim destinatus", and contained brief glosses. Wherefore for a long time law students at Oxford were called "Pauperistae". See Ortolan, Hist. of Rontan Law, $\$ 615$; Colquhoun, Rom. Law, $\$ 144$.

${ }^{28}$ Hunter, Roman Law, 109. 
twelfth century is attested by the historical writings of William of Malmesbury, ${ }^{29}$ who died in 1142 . In the thirteenth century the study of Roman law was introduced at the new University of Cambridge. $^{30}$ And from this time down to the seventeenth century the civil law as a study at the English universities held a rank second only to theology. ${ }^{31}$

From the coming of Vacarius to Oxford near the middle of the twelfth century to the death of Edward I. over a century and a half later, the influence of Roman law on the formation of English law was so great that this whole period should be styled the "Roman epoch of English law."32 During this period, and even as late as the reign of Edward II. ${ }^{33}$ in the first quarter of the fourteenth century, Roman law authorities "were habitually cited in the common law courts, and relied upon by legal writers, not as illustrative and secondary testimonies as at present, but as primary and as practically conclusive". ${ }^{34}$ For instance, early in the fourteenth century in the fifth year of the reign .of Edward II., according to the law reports the Digest of Justinian, book 50, title 17, fragment 14, was directly cited in an English case to prove that where no time is set for the performance of a promise, performance can be demanded at once. ${ }^{35}$

During the middle of the twelfth century Roman law entered England by another channel-via France. The second great code of medieval maritime.law-the Laws of Oleron-was introduced into England from France either by Eleanor, Duchess of Guienne and wife of Henry II., or by their son, Richard I. (Cœur de Lion)..$^{36}$ The Laws of Oleron were inspired by the earlier Consolato del Mare, a compilation based on the Roman civil law. The Laws of Oleron as received into English law were enlarged and perfected in the eighteenth century by Lord Mansfield.

20 See Selden, Dissert., cap. VHI; Amos, Roman Civil Laze, p. 445.

30 The founding of the University of Cambridge is lost in obscurity: it has been put as early as 635 . The first college-Peterhouse-is known to have been definitely established in 1284 .

s1 Bryce, Studies, etc., p. 890.

32 See Güterbock, Bracton, 17; Hunter, Roman Laze", p. 109.

33 Reigned 1307-1327.

34 Amos, Roman Civil Law, p. 450 . See also Selden, Dissert.

35 Amos, Roman Civil Lawe, p. 450.

30 See Act 1403-5, Hen. IV., ch. 7, (Scrutton, Roman Law in Eng., p. 172), where the Admirals swear to judge according to the "Laws of Oleron". 
By the first half of the twelfth century the formation of the common law of England has become clearly visible, ${ }^{37}$ and the commencement of its slow progress to maturity of development begins to be discernible. Its rules and enactments were shaped by Norman lawyers familiar with the Roman and Canon law. The very term "common law" is a borrowing from the Canon law itself: it is an English translation of the Canon law term "jus commune". 38

Trial by jury in English law dates from the institution by Henry II. of the inquest of jurors or recognitors. ${ }^{39}$ What was the origin of the jury? The answers, until recently, have been colored largely by English prejudice. The prevailing opinion ${ }^{40}$ now is that the jury is not of Anglo-Saxon but of Frankish or continental European origin; hence familiar to the Normans and imported into England by them. This Frankish inquest used by the restored Roman Emperor Charlemagne and his royal successors quite naturally seems to imitate certain features of Roman law procedure. ${ }^{41}$ The Roman root-the most important, if not the exclusive source-of the English trial by jury is probably the judices, or persons selected by the prætor in Roman law to determine the facts in legal controversies. The English jury is the most lauded and highly prized feature of the common law. It is the only feature of the English common law which has exertei an universal influence, for it has been copied by numerous modern non-English foreign nations. But in these foreign countries its application has been usually restricted-perhaps wisely-to criminal or penal cases only, civil controversies being tried by the court alone as in Justinian Roman law.

In the reign of Henry II. the royal courts began to issue writs, which were carefully worded and ready-made to suit ordinary cases of litigation. When a litigant desired to sue out a writ he was now enabled to choose an appropriate writ, unless a new one had to be invented. ${ }^{42}$ The drafting of these "ready-made" writs of process must have been greatly facilitated by models of Roman

${ }^{37}$ In the reign of Henry II. (1154-1189). See Holdsworth, History of English Lare, Vol. II, p. 107-169, especially p. 150 (IV).

38 Maitland, Canon Law in England,.p. 4: Pollock and Maitland, History ${ }^{2}$, Vol. I, p. 176.

391 Pollock and Maitland, History², Vol. I, p. 138.

${ }^{40}$ Id., Vol. I, p. 140-142.

41 See Pollock and Maitland, History,", Vol. I, p, 141.'

421 Pollock and Maitland. History ${ }^{2}$, Vol. I. p. 151. 
law formula to be found in the sources of Roman law,-the law familiar to the then ecclesiastical English judges.

Late in the twelfth century appeared the earliest known work on English law. It was writen in Latin. Its author was Glanville, an ecclesiastic, who was Chief Justiciar of England during the reigns of Henry II. and his son, Richard I. (Cour de Lion). ${ }^{43}$ Glanville's work was entitled, "A Treatise on the Laws and Customs of the Kingdom of England." 4 It is more of a manual of procedure and practice than a treatise on law. In his preface Glanville imitates the promium or preface of the Institutes of Justinian, and draws upon the Roman law in his discussion of agreements and contracts, although he calls Roman law a "foreign law".

About a quarter of a century after Glanville, Magna Charta was promulgated, in 1215. This work of that master mind, Cardinal Stephen Langton, Archbishop of Canterbury, must have been suggested to him from some source. It was the result of long-continued agitation for a return to the good old legislation of Edward the Confessor, it proclaimed trial by jury, and it is the cornerstone of English and American civil liberties. Where did Stephen Langton get his inspiration? Not from the then feudalistic institutions in the state. Whatever was remembered of Roman civilization as created by Roman law was preserved through the beneficent influence of the medieval church. Here is an interesting fact. About seventy years before Magna Charta the tradition is that in the little Italian city of Amalfi was found a copy of the Digest of Justinian alleged to have belonged to that emperor himself. At any rate, even if this romantic story is false, ${ }^{45}$ there was discovered somewhere in Italy about this time a splendid manuscript of the Digest, now known as the Florentine, ${ }^{46}$ which became very largely instrumental in causing the wonderful Bologna revival of Roman law study which spread over all western Europe. The source of Archbishop Langton's inspiration is plain: Magna Charta was drafted in the light of civil liberty as proclaimed in Roman law.

43 They reigned from $1154-1199$.

44 Tractatus de legibus et consuetudinibus regni Angliae". See Catholic Encycl., Vol. 6, "Glanville".

45 So proved by Savigny, Geschichte, ch. 17; Rashdall, Universities of Europe in the Middle Ages, Vol. I, 99-100.

16 It is now preseryed in the Medicean Library at Florence. 
A half century after Magna. Charta and in the middle of the thirteenth century flourished the first scientific English jurist,Bracton, also an ecclesiastic, Chief Justiciar of England for two years (1265-1267), in the reign of Henry III. It is said that Bracton was a student of law at Oxford, where he is further alleged to have taken the degree of Doctor of Civil and Canon Law ;7 but proof of this is lacking, although his familiarity with the Roman law would seem to supply it. Bracton's famous work, "Of the Laws and Customs of England", ${ }^{48}$ was written in Latin about 1258.49 Although bearing almost the same title as Glanville's work, it is not a mere treatise on practice, but an exposition of the law itself-the first of its kind in England. And Bracton's treatise not only "testifies to the influence of Roman law and of its medieval exponents, but at the same time remains a statement of genuine English law $* * *$ so detailed and accurate that there is nothing to match it in the whole legal literature of the Middle Ages". ${ }^{50}$

Bracton's importation of Roman law was extensive. In writing his treatise Bracton followed as a model the plan of the Institutes of Justinian. Bracton shows great familiarity with the other parts of the Justinian Corpus Juris. Bracton also used freely a secondary source of Ruman law, - the Summary (Summa) of the Italian glossator Azo, for Bracton was trained in the School of the Glossators. Bracton is the father of the English common law: 450 decided cases are reported in his Notebook. Bracton successfully attempted to build up the English law of his time from Roman materials. Feudalism which had been introduced into England by William the Conqueror, had no law of personal property: Bracton sought to supply the defect, and extracted from the Institutes of Justinian almost bodily all its law of personal property. For many ages his treatise "Of the Laws and Customs of England" was accepted as the standard text-book of the law. Even three centuries later Sir Edward Coke, that bigoted sixteenth century common law partisan, made a remarkable use of Bracton's work as an authority for existing law in his own works on the common law.

47 Spence, Equitable Jurisdiction, etc., Vol. I, 119 (a).

48 "De Legibus et consuetudinibus Angliae".

49 Pollock and Maitland, History'2, Vol. I, p. 207 give 1250-1258. Güterbock, Bracton (Coxe translation), ch. 1, p. 24 gives 1256-1259.

50 Vinagradoff, The Athenaeum, 19 July, 1884. 
The other English jurists of this period followed and often abridged Bracton. Thornton, ${ }^{51}$ who was Chief Justiciar of England under Edward I., abridged Bracton and called his own work a Summary (Summa), - a technical term of the Italian Glossators:

Fleta, an unknown jurist, perhaps a judge confined in the famous Fleet prison at London, while writing his book, lived in the time of Edward I. Fleta's book was written in NormanFrench, repeats much of Bracton, and imports into English law still more Roman law. It was entitled, "A Commentary of the Laws of England".52 The last of this series of early English jurists was Britton. Britton was also a jurist of the reign of Edward I. He was a Doctor of Laws, and wrote about the year 1290 a book in Norman-French which abbreviates Bracton. ${ }^{\text {.s }}$ His work was called a Summary (Summa), in imitation of the Italian Glossators.

Edward I., whose reign of thirty-five years included the last quarter of the thirteenth and the early part of the fourteenth century, is sometimes flatteringly ${ }^{54}$ but rather erroneously styled the "English Justinian". As many as twenty legal enactments passed in his reign have survived to our own time, and have therefore been confirmed by the verdict of long experience. In this reign the jurisdiction of the superior courts of law was settled, the course of the common law was known and established, and legal remedies for. wrongs and injuries were well settled. The common law was formed not only by legal treatises, such as Bracton's, based on Roman law, but also by judicial decisions made with the aid of principles derived from the same source. To Edward's Chief Justiciaries, among them Thornton, ${ }^{55}$ much praise is due for the part they played in developing English law with the help of Roman law.

The reception of Roman law in England prior to the fourteenth century was, as has been noticed, "not an act of legislation, but a long process of custom". ${ }^{56}$ It was found necessary to supply 210.

${ }^{51}$ Gilbert Thornton. See Pollock and Maitland, History ${ }^{2}$, Vol. I, p.

52 It was written ahout 1290 .--Pollock and Maitland, History', Vol. I, p. 210.

E3 Pollock and Maitland, History ${ }^{2}$, Vol. I, p. 210.

${ }^{54}$ e.g. by Blackstone, Commentaries, Introduction, Section 1, p. 23.

ss See supra; note' 51 .

${ }^{5}$ Hunter, Roman Laze', p. 112. 
the defects of the common law, which; having expended its best energies in developing the feudal system, showed no symptoms toward creating an original commercial and movable property law. Use was therefore made of the Roman law, a complete system of law at hand ready for service. But its use and reception were not always acknowledged by the courts. And this habit and practice gradually increased proportionately with the rise and increase of English prejudice against whatever bore the name "Roman".

Originally this prejudice began in a well-founded English abhorrence of the absolution of the Roman public law. But the repudiation of this "tended to involve the rejection of the Roman private law", ${ }^{57}$-at least openly. English suspicion, prejudice and jealousy of "foreign laws" finally aroused much hostility to Roman law. Evidence of this English hostility is seen in the futile twelfth century attempt during the reign of Stephen to proscribe the study of Roman law; and also in the memorable thirteenth century outbreak of the barons at the Parliament of Merton in 1236 , who so strenuously objected to any change in the laws of England..$^{58}$ This hostility was especially aimed at the encroaching pretensions of the Canon law, - that ecclesiastical offshoot of Roman law; soon, unfortunately, it also became aimed at the Roman in addition to the Canon law. Both became suspiciously regarded-owing doubtless to the arrogance of the clergy - as but mere instruments to enslave the English people to popes and emperors: hence the efforts made to curtail the authoritative influence in England of the Roman laws. To such a state of ingratitude did insularity and religious prejudice finally reduce most English jurists until modern times, when at last the debt owed by our law to Roman law began to be paid:

Consequently in later English legal history even to modern times, progress in English law has usualy been paradoxical: namely to take from Roman law new material to be incorporated in English law or to advance its welfare, and at the same time not to acknowledge the Roman law source, or sometimes-what is far worse-even to deny that English law was ever influenced by Roman law. When judges decided cases on principles taken from the Roman law, the theory of the common law was that the

57 Hunter, Roman Law4, ṕ. 112.

58 "Nolimus mutari leges Angliae"; Maitland, Canon Laze in England, p. 53. 
magistrate's decisions came from his inborn wisdom: which theory was often never upset by appropriate mention of the civil law-the only law known as a system of law to the medieval world-as a source of their information. All this has made the English reception of Roman law limited in character as compared with the Continental reception.

But the Romanization of English law has not been small: a summary of specific contributions from Roman to English law reveals the great indebtedness of our law to the law of Rome. Most of the basic principles of the English law of Admiralty, Wills, Successions, Obligations, Contracts, Easements, Liens, Mortgages, Adverse Possession; Corporations, Judgments, Evidence, come from the survival or revival of Roman law in English law. The fundamental conceptions of Habeas Corpus and Trial by Jury as well as many principles of the law of Torts are of Roman origin. That dearly cherished principle and familiar. palladium of English liberty,- "every man's house is his castle",is not of Anglo-Saxon, but of Roman origin. It is first found in the era of the Roman Republic, when the barbarians in Britain or Germany had no houses worthy of the name: Digest $2 ; 4,18$ expressly prohibits forcing a man from his house to drag him to court, thus re-affirming Cicero's statement of the same prohibition. Finally, it is interesting to also note that our statutes resemble somewhat in form the Constitutions of the Roman emperors, and our reported cases the Responsa Prudentium as contained in the Digest.

Faculty of Law, Yale University.

Charles P. Sherman. 